\title{
FAKTOR-FAKTOR YANG MEPENGARUHI AGRESIVITAS PAJAK PADA PERUSAHAAN PROPERTI DAN REAL ESTATE
}

\author{
Ilham Ahmad Maulana \\ Fakultas Ekonomi, Universitas Islam Batik Surakarta, Jawa Tengah-Indonesia \\ maulahmad705@gmail.com
}

DiPublikasi: 01/01/2020

http://dx.doi.org/10.22225/kr.11.2.1178.155-163

\begin{abstract}
In the last 10 years the realization of tax revenue has always never reached the target. One indication is always not achieving the tax target because there is tax aggressiveness carried out by the company. Tax aggressiveness is the act of reducing income taxable through tax planning activities, both legally and illegally. In this research aims to determine and analyze how the influence of Capital Intensity, Profitability, Leverage, Company Size and Inventory Intensity on Tax Aggressiveness. The population of this research are all property and real estate companies listed on the IDX. Sampling used a purposive sampling method to obtain 34 companies. Analysis of the data in this research uses multiple linear regression analysis. The results of this research found that the Capital Intensity, Profitability, and Inventory Intensity variavel affect Tax Aggressiveness, while Leverage and Firm Size do not affect the Tax Aggressiveness. The benefit of this research is to develop theories and knowledge in the field of accounting, especially in taxation related to tax aggressiveness and for investors can be considered when investing in order to avoid companies that do tax aggressive actions.
\end{abstract}

Keywords: Tax aggressiveness factors; tax; property company

Abstrak

Dalam kurun waktu 10 tahun terakhir realissasi penerimaan pajak selalu tidak pernah mencapai target. Salah satu indikasi selalu tidak tercapainya target pajak karena terdapat agresivitas pajak yang dilakukan oleh perusahaan. Agresivitas pajak adalah tindakan menurunkan penghasilan yang dikenaka pajak melalui kegiatan perencanaan pajak, baik secara legal maupun ilegal. Dalam penelitian ini bertujuan untuk mengetahui dan menganalisis bagaimana pengaruh Capital Intensity, Profitabilitas, Leverage, Ukuran Perusahaan dan Inventory Intensity terhadap Agresivitas Pajak. Populasi dari penelitian ini adalah seluruh perushaan Properti dan Real Estate yang terdaftar di BEI. Pengambilan sampel menggunakan metode purposive sampling sehingga diperoleh 34 perusahaan. Analisa data dalam penelitian ini menggunakan analisis regresi linear berganda. Hasil dari penelitian ini diperoleh bahwa variavel Capital Intensity, Profitabilitas, dan Inventory Intensity berpengaruh terhadap Agresivitas Pajak, sedangkan Leverage dan Ukuran Perusahaan tidak berpengaruh terhadap Agresivitas Pajak. Manfaat dari penelitian ini adalah untuk mengembangkan teori serta pengetahuan dalam bidang akuntansi, khususnya dalam perpajakan yang berkaitan denagn agresivitas pajak dan bagi investor dapat menjadi pertimbangan saat menanamkan modalnya agar terhindar dari perusahaan yang melakukan tidakan pajak agresif.

Kata Kunci: Faktor-faktor agresivitas pajak; pajak; perusahaan properti

\section{PENDAHULUAN}

Pajak adalah iuran dari masyarakat kepada negara yang diatur menurut undang-undang dengan tidak mendapatkan prestasi kembali secara langsung yang gunanya adalah untuk membiayai pengeluaran yang berhubungan dengan negara dalam rangka penyelengaraan pemerintahan. Dalam kurun waktu tiga tahun terakhir target penerimaan pajak selalu mengalami penurunan namun target tersebut tidak pernah tercapai bahkan dalam 10 tahun terakhir.

Tabel 1

Realisasi dan Target Penerimaan Pajak Tahun 2016-2018

(Triliyun)

\begin{tabular}{cccc}
\hline & Tahun 2016 & Tahun 2017 & Tahun 2018 \\
\hline Target (Rp) & $1.551,7$ & $1.450,9$ & 1.424 \\
Realisasi(Rp) & $1.183,6$ & $1.339,8$ & $1.315,9$ \\
Persentase & $83,4 \%$ & $91 \%$ & $92 \%$ \\
\hline
\end{tabular}

Sumber: Kementerian keuangan 
Dilihat dari tax rasio, Rasio penerimaan pajak Indonesia pada 2016 sebesar 10,33\% terhadap Produk Domestik Bruto (PDB). Angka tersebut menempatkan Indonesia di peringkat ke-7 dari delapan negara di kawasan ASEAN dan juga berada di bawah standar Bank Dunia sebesar 15\%. Di kawasan Asia Tenggara Indonesia hanya unggul diatas Myanmar yang tax rasionya $6,41 \%$. Pajak merupakan salah satu sumber pendapatan terbesar bagi negara dimana pajak menjadi pemegang peranan penting bagi perekonomian khususnya di Indonesia. Oleh sebab itu, pajak harus mendapatkan perhatian khusus bagi pihak terkait terutama dalam pelaksanaan, pengumpulan serta perundang-undangan (Kusumawati dan Hardiningsih, 2016). Sumber pajak di Indonesia bersumber dari Wjib Pajak Orang Pribadi dan badan. Berdasarkan data dari Direktorat Jenderal Pajak (DJP) Sedangkan bagi perusahaan pajak adalah beban yang akan mengurangi laba bersih. Namun dalam pelaksanaannya terdapat perbedaan kepentingan antara wajib pajak dengan pemerintah.

Karakteristik dari pajak yaitu memaksa sehingga banyak dari perusahaan berusaha melakukan perlawanan pajak. Perlawanan ini dapat berupa perlawanan pajak aktif dan perlawanan pajak pasif. Namun perusahaan banyak menggunakan perlawanan pajak aktif diakrenakan untuk mengindari pajak yang diimplementasikan dalam agresivitas pajak (Andhari \& Sukartha, 2017). Agresivitas pajak adalah menjadi salah satu indikator yang digunakan dalam melihat bagaimaan terjadinya penghindaran pajak oleh wajib pajak. Agresivitas pajak dapat dilakukan melalui 2 cara yaitu dengan tax evasion atau tax avoidance (Frank, Lynch, \& Rego, 2009).

Pada Penelitian yang dilakukan oleh (Andhari \& Sukartha, 2017) mengenai pengaruh pengungkapan corporate social responsibility, profitabilitas, inventory intensity, capital intensity dan leverage pada agresivitas pajak menemukan profitabilitas dan capital intensity berperngaruh positif terhadap agresivitas pajak sedangkan pengungkapan corporate social responsibility, inventory intensity dan leverage perpengaruh negatif terhadap agresivitas pajak. Penelitian lainnya oleh (Nurhandono \& Firmansyah, 2017) menemukan hasil yang berbeda yaitu nilai tidak berpengaruh terhadap agresivitas pajak. Sedangkan leverage berpengaruh terhadap agresivitas pajak. Sedangkan penelitian (Nurlaela \& Chomsatu, 2018) yang berjudul Pengaruh
Kepemilikan Terkonsentrasi, Ukuran Perusahaan, Leverage, Capital Intensity Dan Inventory Intensity Terhadap Agresivitas Pajak Di Bursa Efek Indonesia. Dalam penelitian tersebut diperoleh hasil, Ukuran Perusahaan dan Inventory Intensity berpengaruh positif terhadap agresivitas pajak. Kepemilikan Terkonsentrasi, Leverage, dan Capital Intensity tidak berpengaruh positif terhadap agresivitas pajak.

Tujuan dari penelitian ini adalah untuk mengetahui dan menganalisis bagaimana pengaruh Capital Intensity, Profitabilitas, Leverage, Ukuran Perusahaan dan Inventory Intensity terhadap Agresivitas Pajak. Manfaat dari penelitian ini adalah untuk mengembangkan teori serta pengetahuan dalam bidang akuntansi, khususnya dalam perpajakan yang berkaitan denagn agresivitas pajak dan bagi investor dapat menjadi pertimbangan saat menanamkan modalnya agar terhindar dari perusahaan yang melakukan tidakan pajak agresif.

\section{TINJAUAN PUSTAKA}

\section{Teori keagenan (Agency Theory)}

Teori agensi menjelaskan adanya konflik yang akan timbul antara pemilik dan manajemen perusahaan (Jensen \& Meckling, 1976). Adanya pemisahan antara pemilik dengan manajemen perusahaan dapat menimbulkan masalah. Agresivitas pajak dipengaruhi oleh adanya konflik kepentingan antara agen (manajemen) dengan kepentingan yang timbul ketika setiap pihak berusaha untuk mencapai atau mempertahankan tingkat kemakmuran yang dikehendakinya. Perusahaan yang melakukan agesivitas pajak tentu saja juga melalui kebijakan yang diambil oleh manajemen perusahaan guna membangun citra baik perusahaan serta melakukan mencapai laba yang maksimal.Sedangkan bagi pemilik perusahaan (investor) tidak menghendaki adanya agresvitas pajak karena dianggap memanipulasi data laporan keuangan.

\section{Agresivitas Pajak}

Agresivitas pajak adalah suatu kegiatan atau tindakan yang memiliki tujuan untuk mengurangi penghasilan kena pajak perusahaan baik secara aktif maupun illegal guna mengecilkan beban pajaknya sehingga laba perusahaan yang didapatkan menjadi optimal (Novitasari, Ratnawati, \& Silfi, 2017). 


\section{Capital Intensity}

Capital Intensity dapat diartikan bahwa perusahaan yang menginvestasikan asetnya pada aset tetap dan persediaan (Siregar \& Widyawati, 2016). Apabila perushaan memiliki aset tetap yang besar maka secara otomatis mengurangi pambayaran pajak,hai itu dikarenakan aset tetap memiliki beban depresiasi sehingga dapat dijadikan sebagai cara pengurangan pajak (Gupta \& Newberry, 1997).

\section{Profitabilitas}

Profitabilitas adalah bagaimana kemampuan perusahaan untuk mendapatkan laba atau bagaimana efektivitas pengelolaan manajemen perusahaan dalam memcapai laba (Wiagustini, 2010). Apabila nilai profitabilitas tinggi maka perusahaan akan melakukan perencanaan pajak yang matang sehingga kecenderungan melakukan pajak agresif karena agar tetap mendapatkan laba yang optimal (Prakosa, 2014).

\section{Leverage}

Leverage merupakan rasio yang digunakan untuk mengukur sejauh mana aset perusahaan dibiayai oleh utang (Kasmir, 2010). Beban bunga yang ditanggung perusahaan saaat memeiliki utang dapat dimanfaatkan sebagai pengurang penghasilan kena pajak perusahaan untuk menekan beban pajaknya

\section{Ukuran Perusahaan}

Ukuran perusahaan dapat menujukan setabilan serta kemampuan perusahaan dalam melakukan aktivitas ekonominya (Munandar, Nazar, \& Khairunnisa, 2016). Apabila ukuran perusahaan itu besar maka perusahaan tersebut akan dapat menarik perhatian dari pemerintah dan para manajer akan cenderung berlaku patuh atau agresif dalam menentukan kebijakan yang berkaitan dengan pajak.

\section{Inventory Intensity}

Inventory intensity yaitu ukuran seberapa besar persediaan yang diinvestasikan oleh perusahaan (Nofia, 2018). Jika perusahaan yang berinvestasi dalam persediaan yang berada digudang dapat mengakibatkan munculnya biaya penyimpanan serta biaya pemeliharaan (Andhari \& Sukartha, 2017). Dikarenakan hal tersebut dapat menyebabkan beban perusahaan meningkat sehingga secara otomatis dapat menurunkan jumlah laba perusahaan. Apabila laba perusahaan menurun dengan terdapatnya intensitas persediaan yang tinggi maka perusahaan menjadi akan lebih agresif terhadap tingkan beban pajak yang diterima (Andhari \& Sukartha, 2017).

\section{Kerangka Pemikiran}

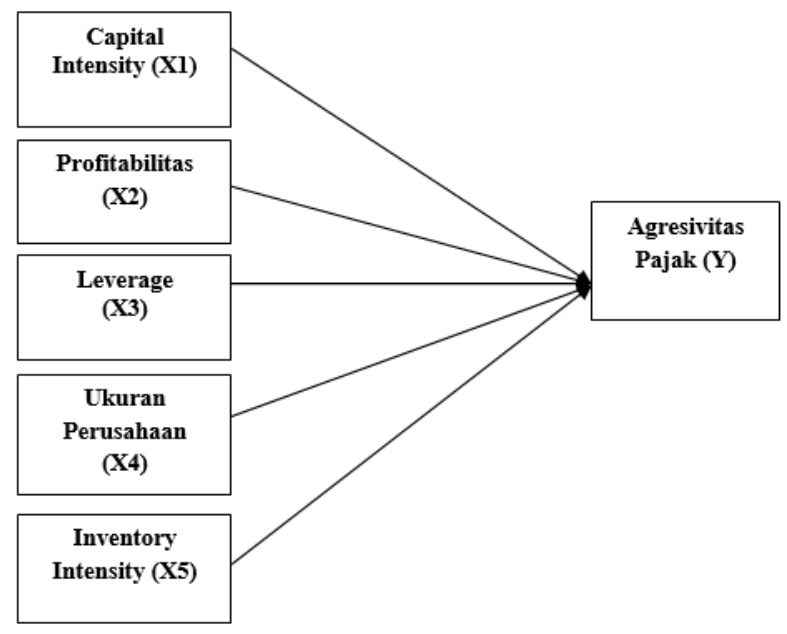

Diagram 1

Kerangka Pemikiran

\section{Hipotesis}

Pengaruh Capital Intensity terhadap Agresivitas Pajak.

Hasil penelitian (Rinaldi \& Cheisviyanny, 2015) menujukan capital intensity berpengaruh pada agresivitas pajak yang diproksikan dengan tax avoidance. (Andhari \& Sukartha, 2017) dalam penelitianya menunjukan hasil bahwa Capital Intensity berpengaruh terhadap agresifitas pajak.

H1 : Capital Intensity Berpengaruh terhadap Agresivitas Pajak

Pengaruh Profitabilitas terhadap Agresivitas Pajak

Penelitian (Fernández-Rodríguez \& MartínezArias, 2012) menujukan bahwa profitabilitas berpengaruh terhadap agresivitas pajak yang di proksikan dengan Effective Tax Rate (ETR)

H2 : Profitabilitas Berpengaruh terhadap Agresivitas Pajak.

\section{Pengaruh Leverage terhadap Agresivitas Pajak}

Penelitian sebelumnya yang menemukan bahwa terdapat pengaruh leverage terhadap agresivitas pajak (Harrington \& Smith, 2012) Hasil penelitian tersebut juga konsisten dengan penelitian di Indonesia yang dilakukan oleh (Kuriah \& Asyik, 2016; Siregar \& Widyawati, 2016; Suyanto \& Supramono, 2012)

H3 : Leverage Berpengaruh terhadap Agresivitas Pajak 


\section{Pengaruh Ukuran Perusahaan terhadap Agresivitas Pajak}

Penelitian oleh (Rusydi, 2013) dengan hipotesis ukuran peusahaan berpengaruh terhadap agresivitas pajak. Penelitan serupa oleh (Tiaras \& Wijaya, 2015) dengan hasil penelitian bahwa ukuran perusahaan memiliki pengaruh terhadap tingkat agresivitas pajak.

H4 : Ukuran Perusahaan Berpengaruh terhadap Agresivitas Pajak

Pengaruh Inventory Intensity terhadap Agresivitas Pajak

Penelitian (Adisamartha \& Noviari, 2015) (Adisamartha \& Noviari, 2015) menunjukan bahwa Inventory intensity (intensitas persediaan) berpengaruh terhadap tingkat agresivitas pajak.

H5 : Inventory Intensity Berpengaruh terhadap Agresivitas Pajak

\section{METODE}

Penelitian termasuk dalam penelitian kauntitatif. Penelitian kuantitatif adalah kuantitatif adalah metode penelitian yang menggunakan proses data-data yang berupa angka sebagai alat menganalisis dan melakukan kajian penelitian, terutama mengenai apa yang sudah di teliti Karisam (2008).Variabel yang digunakan dalam penelitian ini adalah Capital Intensity (X1), Profitabilitas (X2), Leverage (X3), Ukuran Perusahaan (X4), dan Inventory Intensity (X5) sebagai variabel independent, sedangkan untuk variabel dependend adalah Agresivitas Pajak (Y). Sumber data dalam penelitian ini menggunakan data sekunder, sedangakan instrumen yang digunakan dalam penelitian menggunakan dokumentasi (bersumber dari laporan keuangan perusahaan). Populasi yang penelitian yaitu seluruh perusahaan Properti dan Real Estate yang terdaftar di BEI selama 20162017. Pemilihan sampel dalam penelitian ini menggunakan teknik purposive sampling. Metode analisis data menggunakan analisis regresi linear berganda.

Tabel 2

Pengukuran variabel penelitian

\begin{tabular}{|c|c|c|}
\hline No & Variabel & Cara Pengukuran \\
\hline 1. & Agresivitas Pajak & $\begin{array}{c}\text { ETR }=\frac{\text { Beban pajak penghasilan }}{\text { Pendpatan sebelum pajak }} \\
\text { (Lanis \& Richardson ,2012) }\end{array}$ \\
\hline 2. & Capital Intennsity & $\begin{array}{c}\text { CINT }=\frac{\text { Total Aset Bersih }}{\text { Total Aset }} \\
\text { (Agus Sartono ,2001) }\end{array}$ \\
\hline 3. & Profitabilitas & $\begin{array}{l}\text { ROA }=\frac{\text { Earning After tax }}{\text { Modal sendiri }} \\
\text { (Brigham \& houston, 2001) }\end{array}$ \\
\hline 4. & Leverage & $\begin{array}{c}\text { LEV }=\frac{\text { Hutang Jangka Panjang }}{\text { Total Aset }} \\
\text { (Farooque et al., 2014) }\end{array}$ \\
\hline 5. & Ukuran Perusahaan & $\begin{array}{c}\text { SIZE }=\text { LN (Total Aset) } \\
\text { (Husodo 2017) }\end{array}$ \\
\hline 6. & Inventory Intensity & $\begin{array}{c}\text { INVINT }=\frac{\text { Total Pesediaan }}{\text { Total Aset }} \\
\text { (Darmadi 2013). }\end{array}$ \\
\hline
\end{tabular}




\section{HASIL DAN PEMBAHASAN}

Tabel 3

Pemilihan sampel

\begin{tabular}{clc}
\hline No & \multicolumn{1}{c}{ Kriteria } & Jumlah \\
\hline 1. & Perusahaan sektor Properti dan Real Estate 2016-2017 & 51 \\
2. & Perusahaan yang delisting selama periode penelitian & $(3)$ \\
3. & Perusahaan yang mengalami kerugian sebelum pajak selama & $(7)$ \\
& periode 2017-2016 & 82 \\
4. & Data outlier $\quad$ Jumlah sampel perusahaan periode 2016-2017 & $(30)$ \\
& & 52 \\
\hline
\end{tabular}

Sumber : Lampiran

\section{Uji Asumsi Klasik}

Uji Normalitas (Kolmogorov-Smirnov)

Tabel 4

Uji Normalitas

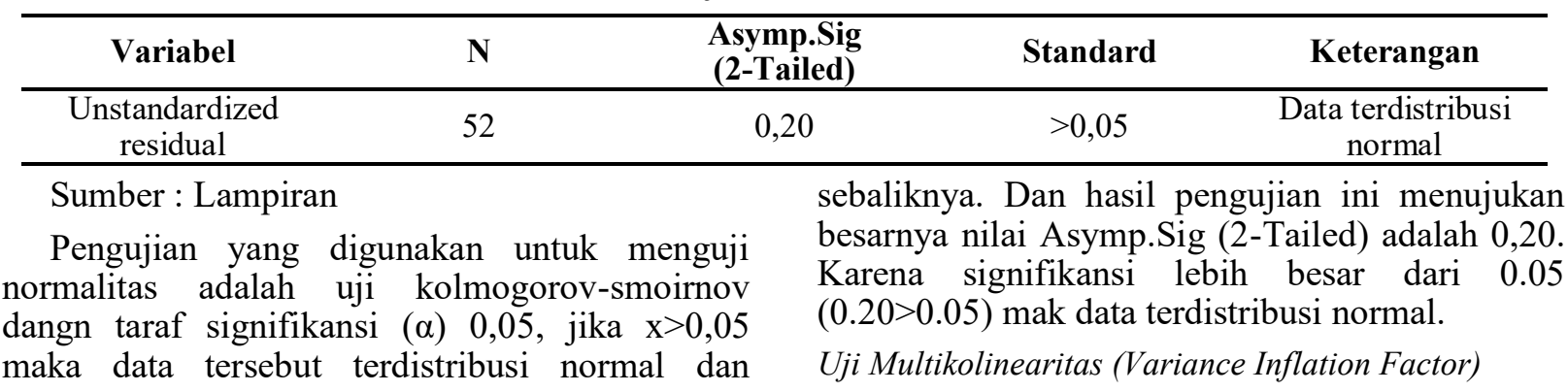

Tabel 5

Uji Multikolinearitas

\begin{tabular}{cccccc}
\hline Variabel & Tolerance & Standard & VIF & Standard & Keterangan \\
\hline Capital intensity & 0.796 & $>0,10$ & 1,256 & $<10$ & Bebas Multikoleniaritas \\
Profitabilitas & 0.925 & $>0,10$ & 1,082 & $<10$ & Bebas Multikoleniaritas \\
Leverage & 0,901 & $>0,10$ & 1,110 & $<10$ & Bebas Multikoleniaritas \\
Ukuran & 0,938 & $>0,10$ & 1,066 & $<10$ & Bebas Multikoleniaritas \\
Perushaan & $>0,10$ & 1,196 & $<10$ & Bebas Multikoleniaritas \\
Inventory & 0,836 & $>0,10$ &
\end{tabular}

Sumber : Lampiran

Uji Multikolinearitas ini bertujuan untuk menguji apakah suatu model regresi terdapat korelasi antar variabel bebas (independen).
Berdasarkan tabel diatas, nilai toleransi $>0,10$ dan nilai VIF $<10$. Maka tidak terjadi multikoleniaritas dalam penelitian ini.

Uji Autokorelasi (Runs Test)

Tabel 6

Uji Autokorelasi

\begin{tabular}{cccc}
\hline Variabel & $\begin{array}{c}\text { Asymp.Sig } \\
\text { (2-Tailed) }\end{array}$ & Standard & Keterangan \\
\hline Unstandardized residual & 0,779 & 0,05 & Tidak terjadi autokorelasi \\
\hline
\end{tabular}


Faktor-Faktor yang Mepengaruhi Agresivitas Pajak pada Perusahaan Properti dan Real Estate

Sumber : Lampiran

Berdasarkan uji Runs Test dapat diketahui nilai Asymp.Sig (2-Tailed) sebesar 0,779 lebih besar dari $>0,05$ sehingga dapat disimpulkan tidak terjadi msalah autokorelasi.

Uji Heteroskedastisitas (Sperman's Rho)

Tabel 7

Uji Heteroskedastisitas

\begin{tabular}{cccc}
\hline Variabel & Sig.(2-tailed) & Standard & Keterangan \\
\hline Capital Intensity & 0,762 & $>0,05$ & Tidak ada Heteroskedastisitas \\
Profitabilitas & 0,567 & $>0,05$ & Tidak ada Heteroskedastisitas \\
Leverage & 0,780 & $>0,05$ & Tidak ada Heteroskedastisitas \\
Ukuran Perusahaan & 0,590 & $>0,05$ & Tidak ada Heteroskedastisitas \\
Inventory Intensity & 0,810 & $>0,05$ & Tidak ada Heteroskedastisitas \\
\hline
\end{tabular}

Pada penelitian ini uji heteroskesdastisitas menggunakan metode Sperman's Rho. Hasil dari uji heteroskesdastisitas adalah nilai Sig.(2-tailed) pada setiap variabel lebih dari $>0,05$ sehinga dapat disimpulkan tidak ada masalah

heteroskesdastisitas.

\section{Uji Regresi Linear Berganda}

Model Regresi

Tabel 8

Model Regesi

\begin{tabular}{cc}
\hline Model & B \\
\hline (Constant) & 0.088 \\
CINT & 0,142 \\
ROA & 0,646 \\
LEV & 0,221 \\
SIZE & 0,002
\end{tabular}

\begin{tabular}{lll}
\multicolumn{1}{c}{ INVINT } & & 0,140 \\
\cline { 2 - 3 } Sumber: Lampiran & CINT & $=$ Capital Intensity \\
Y $=0,088-0,142$ CINT $+0,646$ ROA $+0,221$ & ROA & $=$ Profitabilitas \\
LEV $+0,002$ SIZE + & SIZE & $=$ Ukuran Perusahaan \\
0,140 INVINT + e & INVINT & $=$ Inventory Intensity
\end{tabular}

Keterangan :

$\begin{array}{ll}\alpha & =\text { Konstanta } \\ \mathrm{Y} & =\text { Agresivitas Pajak }\end{array}$

$\beta 1, \beta 2, \beta 3, \beta 4, \beta 5=$ Koefisien regresi parsial

e $\quad=$ Error

Uji Kelayakan Model

Tabel 9

Uji Kelayakan Model

\begin{tabular}{|c|c|c|c|c|c|}
\hline Model & F hitung & F tabel & Sig & Standard & Keterangan \\
\hline Regresi 1 & 2,942 & 2,363 & 0,019 & $<0,05$ & Model layak \\
\hline \multicolumn{3}{|c|}{$\begin{array}{l}\text { Sumber : Lampiran } \\
\text { Uji F ini dilakukan untuk menguji secara } \\
\text { simultan variabel independen mempunyai } \\
\text { pengaruh terhadap variabel dependen. Hasil uji } \\
\text { stastitik F menujukan F Hitung }>\text { F Tabel }\end{array}$} & \multicolumn{3}{|c|}{$\begin{array}{l}(2,942>2,363) \text { dan nilai Sig }<0,05 \text {. Hal ini } \\
\text { menunjukkan bahwa secara simultan atau } \\
\text { bersama-sama variabel independen memiliki } \\
\text { pengaruh signifikan terhadap variabel dependen. } \\
\text { Artinya Capital Intensity (X1), Profitabilitas (X2), } \\
\text { Leverage (X3), Ukuran Perusahaan (X4), dan }\end{array}$} \\
\hline
\end{tabular}




\begin{tabular}{|c|c|c|c|c|c|c|}
\hline $\begin{array}{l}\text { Inventor } \\
\text { berpeng } \\
\text { Uji hipot } \\
\quad \text { Uji } \\
\text { secara }\end{array}$ & $\begin{array}{l}\text { gry Intensity } \\
\text { garuh terhadap } \\
\text { tesis (Uji t) } \\
\mathrm{t} \text { digunakan } \\
\text { parsial varia }\end{array}$ & $\begin{array}{l}\text { 5) secara } \\
\text { gresivitas } \\
\text { ntuk men } \\
\text { 1 Capital }\end{array}$ & $\begin{array}{l}\text { persama- } \\
\text { ijak (Y). } \\
\text { tahui ar } \\
\text { tensity }\end{array}$ & $\begin{array}{l}\text { ma } \\
\text { (ah } \\
1), \\
\text { Tabel } \\
\text { Jji Hipo }\end{array}$ & \multicolumn{2}{|c|}{$\begin{array}{l}\text { Profitabilitas (X2), Leverage (X3), } \\
\text { Perusahaan (X4), dan Inventory Intens } \\
\text { terhadap Agresivitas Pajak (Y). Beriku } \\
\text { hasil pengujian hipotesis masin } \\
\text { variabel: }\end{array}$} \\
\hline & Hipotesis & T hitung & $T$ tabel & Sig & Standard & Keterangan \\
\hline & $\mathrm{X} 1$ & $-2,848$ & $-1,999$ & 0,006 & $<0,05$ & Diterima \\
\hline & $\mathrm{X} 2$ & 2,498 & 1,999 & 0,015 & $<0,05$ & Diterima \\
\hline & $\mathrm{X} 3$ & 1,870 & 1,999 & 0,066 & $<0,05$ & Ditolak \\
\hline & $\mathrm{X} 4$ & 0,679 & 1,999 & 0,499 & $<0,05$ & Ditolak \\
\hline & X5 & 2,114 & 1,999 & 0,039 & $<0,05$ & Diterima \\
\hline
\end{tabular}

Sumber: Lampiran

Uji Koefisien Determinasi (R2)

Tabel 11

Uji Koefisien Determinasi

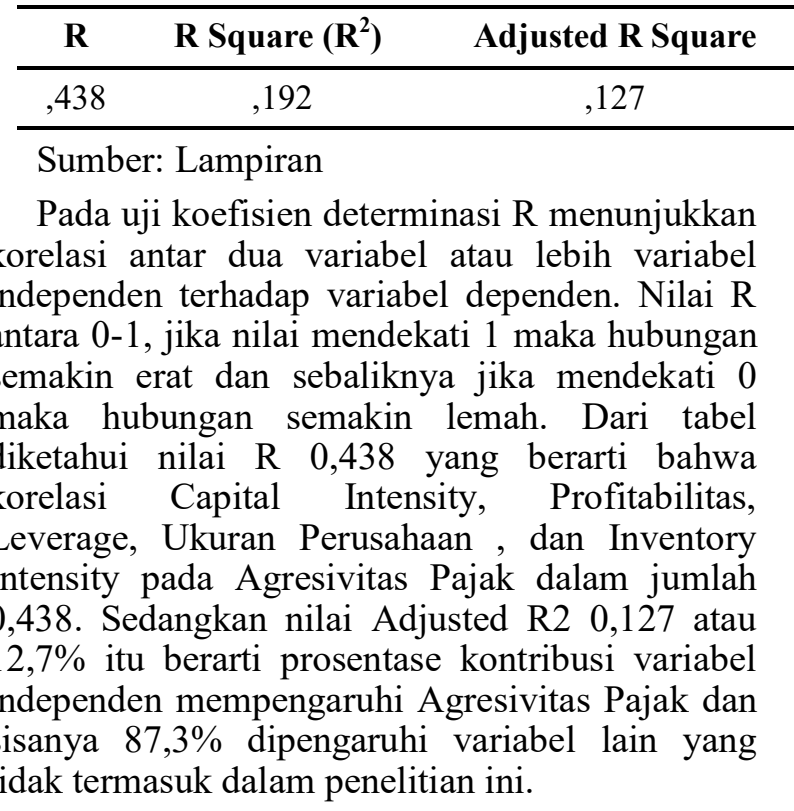

\section{Pembahasan}

Berdasarkan hasil uji hipotesis diatas dijelaskan sebagai berikut : 1). Pengujian hasil hipotesis Capital Intensity (X1) mempengaruhi Agresivits Pajak. Hal ini menandakan bahwa ketika capital intensity meningkat maka perusahaan akan semakin agresif terhadap kewajiban perpajakan perusahaanya. Hasil penelitian ini sejalan dengan yang dilakukan oleh (Andhari \& Sukartha, 2017; Surbakti, 2012) yang
Std.Error of the Estimate $\quad$ Keterangan

,08084 Berpengaruh $12,7 \%$

menujukan Capital Intensity berpengaruh terhadap Agresivitas Pajak. 2) Hasil pengujian hipotesis kedua Profitabiltas (X2) berpengaruh positif terhadap Agresivitas Pajak. Semakin besar perusahaan memperoleh laba, maka semakin agresif pula perusahaan melakukan praktik penghindaran akan kewajiban perpajakannya. Hasil penelitian ini sejalan dengan penilitian yang dilakukan oleh (Andhari \& Sukartha, 2017; Hayu, 2015; Rinaldi \& Cheisviyanny, 2015) yang menujukan Profitabilitas berpengaruh terhadap Agresivitas Pajak. 3) Pengujian hipotesis ketiga Leverage (X3) menunjukan hasil bahwa leverage tidak mempengaruhi Agresivitas Pajak. Hal ini menunjukkan bahwa semakin besar nilai utang perusahaan maka semakin rendah praktik penghindaran pajak yang dilakukan oleh perusahaan. Penelitian ini sejalan dengan penelitian yang dilakukan oleh (Darmawan \& Sukartha, 2014; Kurniasih \& Sari, 2013; Tiaras \& Wijaya, 2015). 4) Hasil pengujian hipotesis Ukuran Perusahaan (X4) tidak memiliki pengaruh terhadap Agresivitas Pajak. Hasil tersebut menunjukkan bahwa ada kemungkinan perusahaan menengah maupun kecil juga melakukan agresivitas pajak. Jadi tidak hanya perusahaan besar yang melakukannya. Hal ini disebabkan karena pajak masih dianggap sebagai 
beban baik untuk perusahaan maupun oleh orang pribadi. Hasil penelitian ini sejalan dengan (Susanto, Yanti, \& Viriany, 2018) bahwa ukuran perusahaan tidak berpenagruh terhadap agrsivitas pajak. 5) Hasil pengujian hipotesis Inventory Intensity (X5) berpengaruh terhadap Agresivitas Pajak. Artinya intensitas persediaan yang tinggi akan meningkatkan laba bersih perusahaan karena biaya-biaya yang terkandung dalam persediaan mampu diefisienkan. Perusahaan akan meningkatkan persediaan akhir guna mengurangi intensitas persediaan dan meningkatkan biayabiaya yang terkandung di dalam perusahaan untuk mengurangi laba bersih dan berkurangnya beban pajak. Hasil penelitian sejalan dengan (Nurlaela \& Chomsatu, 2018) bahwa inventory intensity berpengaruh terhadap Agresivitas Pajak.

\section{SIMPULAN}

Dari hasil penelitian yang telah dilakukan dapat disimpulkan bahwa secara parsial Capital Intensity , Profitabilitas, Leverage, Ukuran Perusahaan dan Inventory Intensity tidak berpengruh terhadap Agresivitas Pajak. Capital Intensity, Profitabilitas, dan Inventory Intensity berpengaruh positif terhadap Agresivitas Pajak. Sedangkan Leverage dan Ukuran Perusahaan berpengaruh negatif terhadap Agresivitas Pajak. Untuk pengaruh secara simultan Capital Intensity , Profitabilitas, Leverage, Ukuran Perusahaan dan Inventory Intensity tidak berpengruh terhadap Agresivitas Pajak pada perusahaan Properti dan Real Estate yang terdaftar di BEI 2016-2017. Hasil penelitian ini tidak dapat di generalisir karena penelitian ini hanya dilakukan pada perusahaan Properti dan Real Estate saja.

\section{DAFTAR PUSTAKA}

Adisamartha, I. B. P. F., \& Noviari, N. (2015). Pengaruh Likuiditas, Leverage, Intensitas Persediaan Dan Intensitas Aset Tetap Pada Tingkat Agresivitas Wajib Pajak Badan. E-Journal Akuntansi Universitas Udayana, 13(3), 973-1000. Retrieved from https:// ojs.unud.ac.id/index.php/Akuntansi/article/ view/14496

Andhari, P. A. S., \& Sukartha, I. M. (2017). Pengaruh Pengungkapan Corporate Social Responsibility, Profitabilitas, Inventory Intensity, Capital Intensity Dan Leverage Pada Agresivitas Pajak. E-Journal Akuntansi Universitas Udayana, 18(3), 2115-2142. Retrieved from https://ojs.unud.ac.id/index.php/ Akuntansi/article/view/25794

Darmawan, I. G. H., \& Sukartha, I. M. (2014). Pengaruh Penerapan Corporate Governance, Leverage, Roa, Dan Ukuran Perusahaan Pada Penghindaran Pajak. E -Journal Akuntansi Universitas Udayana, 9(1), 143-
161. Retrieved from https://ojs.unud.ac.id/index.php/ Akuntansi/article/view/8635

Fernández-Rodríguez, E., \& Martínez-Arias, A. (2012). Do Business Characteristics Determine an Effective Tax Rate? Chinese Economy, 45(6), 60-83. Retrieved from https://www.researchgate.net/ publication/269484388_Do_Business_Characteristic s_Determine_an_Effective_Tax_Rate

Frank, M. M., Lynch, L. J., \& Rego, S. O. (2009). Tax Reporting Aggressiveness and Its Relation to Aggressive Financial Reporting. American Accounting Association, 84(2), 467-496. Retrieved from https://doi.org/10.2308/accr.2009.84.2.467

Gupta, S., \& Newberry, K. (1997). Determinants of the variability in corporate effective tax rates: Evidence from longitudinal data. Journal of Accounting and Public Policy, 16(1), 1-34. Retrieved from https:// doi.org/10.1016/S0278-4254(96)00055-5

Harrington, C., \& Smith, W. (2012). Tax Avoidance and Corporate Capital Structure. Journal of Finance and Accountancy, 1-20. Retrieved from https:// www.aabri.com/manuscripts/121289.pdf

Hayu, P. (2015). Analisis Empiris Pengaruh Aktivitas Corporate Social Responsibility (CSR) terhadap Penghindaran Pajak di Indonesia. Program Pasca Sarjana, Universitas Gadjah Mada.

Jensen, M. C., \& Meckling, W. H. (1976). Theory of the firm: Managerial behavior, agency costs and ownership structure. Journal of Financial Economics, 3(4), 305-360. Retrieved from https:// doi.org/10.1016/0304-405X(76)90026-X

Kasmir. (2010). Pengantar Manajemen Keuangan. Jakarta: Kencana Prenada Media Group.

Kuriah, H. L., \& Asyik, N. F. (2016). Pengaruh karakteristik perusahaan dan corporate social responsibility terhadap agresivitas pajak. Jurnal Ilmu Dan Riset Akuntansi, 5(3), 1-19.

Kurniasih, T., \& Sari, M. M. R. (2013). Pengaruh Return On Assets, Leverage, Corporate Governance, Ukuran Perusahaan Dan Kompensasi Rugi Fiskal Pada Tax Avoidance. Buletin Studi Ekonomi, 18(1). Retrieved from https://ojs.unud.ac.id/index.php/bse/article/ view/6160

Munandar, R. T., Nazar, M. R., \& Khairunnisa. (2016). Pengaruh Ukuran Perusahaan, Leverage, Dan Kompensasi Rugi Fiskal Terhadap Tax Avoidance (studi Kasus Pada Perusahaan Manufaktur Subsektor Otomotif Yang Terdaftar Di Bursa Efek Indonesia Tahun 2010-2014). In E-Proceedings of Management Telkom University (pp. 3417-3424). Retrieved from https:// libraryeproceeding.telkomuniversity.ac.id/index.php/ management/article/view/3349

Nofia, U. L. (2018). Pengaruh Corporate Govermance,Capital Intensity dan Inventory Intensity Terhadap Agresivitas Pajak Persahaan Manufaktur yang Terdaftar di BEI. Jurusan Akuntansi Syariah Fakultas Ekonomi Dan Bisnis Islam Institut Agama Islam Negeri Surakarta. Retrieved from http://eprints.iainsurakarta.ac.id/1593/1/SKRIPSI FULL.pdf

Novitasari, S., Ratnawati, V., \& Silfi, A. (2017). Pengaruh Manajemen Laba, Corporate Governance, Dan Intensitas Modal Terhadap Agresivitas Pajak 
Perusahaan (Studi Empiris pada Perusahaan Property dan Real Estate yang Terdaftar di BEI Periode Tahun 2010-2014). Jurnal Online Mahasiswa (JOM) Fakultas Ekonomi Universitas Riau, 4(1), 19011914. Retrieved from https://jom.unri.ac.id/ index.php/JOMFEKON/article/view/13314

Nurhandono, F., \& Firmansyah, A. (2017). Pengaruh Lindung Nilai, Financial Leverage, Dan Manajemen Laba Terhadap Agresivitas Pajak. Media Riset Akuntansi, Auditing \& Informasi, 17(1). Retrieved from https://www.trijurnal.lemlit.trisakti.ac.id/ index.php/mraai/article/view/2039

Nurlaela, M. F. S., \& Chomsatu, Y. (2018). Pengaruh Kepemilikan Terkonsentrasi, Ukuran Perusahaan, Leverage, Capital Intensity Dan Inventory Intensity Terhadap Agresivitas Pajak. Paradigma, 19(2). Retrieved from https://journal.uniba.ac.id/index.php/ $\mathrm{PRM} /$ article/view/7

Prakosa, B. (2014). Pengaruh Profitabilitas, Kepemilikan Keluarga dan Corporate Governance Terhadap Penghindaran Pajak Di Indonesia. In Simposium Nasional Akuntansi XVII. Lombok.

Rinaldi, \& Cheisviyanny, C. (2015). Pengaruh Profitabilitas, Ukuran Perusahaan dan Kompensasi Rugi Fiskal terhadap Tax Avoidance (Studi Empiris pada Perusahaan Manufaktur Yang terdaftar di BEI Tahun 2010- 2013). In Seminar Nasional Ekonomi Manajemen dan Akuntansi Fakultas Ekonomi Universitas Negeri Padang (pp. 472-483). Retrieved from http://fe.unp.ac.id/sites/default/files/ unggahan/14. Rinaldi\%2C Charoline Cheisviyanny \%28hal 472-483\%29_0.pdf

Rusydi, M. K. (2013). Pengaruh Ukuran Perusahaan Terhadap Aggressive Tax Avoidance Di Indonesia. Jurnal Akuntansi Multiparadigma, 4(2). Retrieved from http://dx.doi.org/10.18202/jamal.2013.08.7200

Siregar, R., \& Widyawati, D. (2016). Pengaruh karakteristik perusahaan terhadap penghindaran pajak pada perusahaan manufaktur di BEI. Jurnal Ilmu Dan Riset Akuntansi, 5(2). Retrieved from https:// www.semanticscholar.org/paper/PENGARUHKARAKTERISTIK-PERUSAHAAN-TERHADAPPAJAK-DI-Siregar-

Widyawati/8582fd9d0b6afb5c22f8938108a6e270d9d $53 \mathrm{e} 1 \mathrm{~b}$

Surbakti, T. A. V. (2012). Pengaruh Karakteristik Perusahaan dan Reformasi Perpajakan Terhadap Penghindaran Pajak di Perusahaan Industri Manufaktur yang Terdaftar di Bursa Efek Indonesia Tahun 2008-2010. Jurnal Akuntansi Fakultas Ekonomi Universitas Indonesia.

Susanto, L., Yanti, \& Viriany. (2018). Faktor-faktor yang mempengaruhi agresivitas pajak. Jurnal Ekonomi Universitas Tarumanegara, 23(1). Retrieved from http://dx.doi.org/10.24912/je.v23i1.330

Suyanto, K. D., \& Supramono. (2012). Likuiditas, Leverage, Komisaris Independen, Dan Manajemen Laba Terhadap Agresivitas Pajak Perusahaan. Jurnal Keuangan Dan Perbankan, 16(2). Retrieved from http://jurnal.unmer.ac.id/index.php/jkdp/article/ view/1057

Tiaras, I., \& Wijaya, H. (2015). Pengaruh Likuiditas, Leverage, Manajemen Laba, Komisaris Independen Dan Ukuran Perusahaan Terhadap Agresivitas Pajak.
Jurnal Akuntansi Universitas Tarumanegara, 19(3).

Retrieved from http://dx.doi.org/10.24912/ ja.v19i3.87

Wiagustini, N. L. P. (2010). Dasar-Dasar Manajemen Keuangan. Denpasar: Udayana University Press. 